\title{
MITOCHONDRIAL DNA VARIATION IN THE ENDANGERED FISH DAWKINSIA TAMBRAPARNIEI (ACTINOPTERYGII: CYPRINIFORMES: CYPRINIDAE) FROM SOUTHERN WESTERN GHATS, INDIA
}

\author{
Karuppiah KANNAN, Jeyaraj A. JOHNSON*, Ajit KUMAR, and Sandeep K. GUPTA \\ Wildlife Institute of India, 18 Chandrabani, Dehradun, 248001, Uttarkhand, India
}

\begin{abstract}
Kannan K., Johnson J.A., Kumar A., Gupta S.K. 2014. Mitochondrial DNA variation in the endangered fish Dawkinsia tambraparniei (Actinopterygii: Cypriniformes: Cyprinidae) from southern Western Ghats, India. Acta Ichthyol. Piscat. 44 (1): 3-8.
\end{abstract}

Background. Dawkinsia tambraparniei (Silas, 1954) is confined to an area not exceeding $100 \mathrm{~km}^{2}$ within a single watershed - the Tamiraparani River, southern Western Ghats, India. Its populations have recently declined, earning the fish the endangered status. For effective conservation efforts it is important to determine the levels of genetic variation between different populations. Therefore we attempted to quantify the cytochrome $b(\mathrm{Cyt} b)$ and cytochrome c oxidase subunit $I(\mathrm{CO} I)$ gene sequence similarity between different populations of $D$. tambraparniei, as well as to study the phylogenetic relation with the closely related species $D$. arulius and $D$. filamentosa.

Materials and methods. Samples were collected from 9 locations and 10 individuals from each were preserved for DNA analysis. The partial sequence of $\mathrm{Cyt} b$ and $\mathrm{COI}$ genes were amplified and sequenced. The sequences were aligned by the visual method using BioEdit version 7.1.3.0 and edited using Sequencer 4.7. The Bayesian consensus tree was constructed using the Monte Carlo Markov Chain (MCMC) method by BEAST v1.7.5.

Results. The partial sequences of Cyt $b$ and COI from 90 specimens of Dawkinsia tambraparniei representing nine populations were examined. The Cyt $b$ gene sequences showed that all populations belong to a single haplotype and no nucleotide variation was observed between populations. In the case of $\mathrm{CO} I$ gene sequences, two haplotypes were revealed: an additional haplotype with a clear transition of $\mathrm{C}$ to $\mathrm{T}$ at the nucleotide 58 position was detected within the Thalayanai Stream population. The phylogenetic analysis of $\mathrm{COI}$ gene demonstrated that the pair wise genetic distance between $D$. tambraparniei and D. arulius was low $(0.004 \pm \mathrm{SE} 0.003)$ when compared with the distance between $D$. tambraparniei and D. filamentosa $(0.061 \pm \mathrm{SE} 0.012)$.

Conclusion. The mitochondrial DNA analysis revealed very low diversity among investigated populations of $D$. tambraparniei for studied genes, with the only local population from the Thalayanai Stream demonstrating certain divergence. The phylogenetic analysis confirms the concept on the validity of $D$. tambraparniei as a separate species. This phylogenetic study also demonstrated that $D$. tambraparniei is closer to D. arulius, followed by D. filamentosa.

Keywords: endemic cyprinids, cytochrome $b$, cytochrome c oxidase $I$, phylogenetic tree

\section{INTRODUCTION}

Dawkinsia tambraparniei (Silas, 1954) is a small fish, commonly known as Tamiraparani barb, and it is very popular in aquarium trade because of its brilliant body and fin colour. It was originally described by Silas (1954) as a subspecies of Dawkinsia arulius (Jerdon, 1849) (= "Puntius arulius") occurring in the Cauvery River basin, India. D. tambraparniei has been confined to a single watershed, namely the Tamiraparani River in southern Western Ghats, India. This species is distributed in many parts of Tamiraparani River including tributaries, mid-streams, lower stretches of the river, as well as riverassociated wetlands. In recent years, populations of $D$. tambraparniei have declined gradually due to human activities such as sand mining, habitat alterations, and collection of wild stock for the aquarium trade. Currently, the distribution range of this species is restricted to less than $100 \mathrm{~km}^{2}$. Because of these threats and restricted distribution, D. tambraparniei was assessed as endangered in the IUCN red list (Dahanukar 2011). In order to conserve and effectively manage this endemic species, including the development of strategies to maintain genetic diversity, it is important to determine the levels of genetic variation between different populations. In this context, molecular techniques have provided new and better insights into the fields of taxonomy, population

\footnotetext{
* Correspondence: Dr. J.A. Johnson, Scientist-D, Department of Habitat Ecology, Wildlife Institute of India, 18, Chandrabani, Dehradun 248 001, Uttarakhand, India, phone: +91 135 2640112, ext. 285, fax: +91 135 2640117, e-mail: (JAJ) jaj@wii.gov.in; (KK) kanna.k84@gmail.com; (KA) ajitkumar@wii.gov.in; (GSK)skg@wii.gov.in.
} 
structure, and conservation management of species. Different molecular markers have been used for the identification of species, phylogenetic studies, and also to quantify the specific genetic variations between and within populations. Among the markers, the maternally inherited mitochondrial DNA markers like cytochrome $b$ (Cyt $b$ ) and cytochrome c oxidase subunit $I(\mathrm{CO} I)$ gene are widely used in molecular studies. These markers generally exhibit 5 to 10 time greater variability than single copy nuclear genes, and have been used as a molecular tool for estimating phylogenetic relations in various groups of species (Chan et al. 2009). This molecular information provides a clear understanding of ecological and adaptive characteristics as well as historical and genetic variation among populations, which is necessary for the conservation of species as evolutionary entities. Information on the patterns of genomic diversity of $D$. tambraparniei has not been known, except for a preliminary study on cytogenetic diversity by Arunachalam and Murugan (2007). Thus, the presently reported study aimed to quantify the Cyt $b$ and $\mathrm{COI}$ gene sequence diversity between different populations of D. tambraparniei, as well as to study the phylogenetic relation with the closely related species $D$. arulius and D. filamentosa (Valenciennes, 1844).

\section{MATERIALS AND METHODS}

Sample collection. Fish were collected between December 2010 and July 2011 from nine sampling sites (Fig. 1), of which six locations were from the main tributaries of the Tamiraparani River, namely Manimuthar, Thalayanai, Karayar, Servalar, Kallar, and Illuppaiyar rivers, and three locations from the downstream reaches of the Tamiraparani River at Kokkarakulam, Chittar, and Marudur. Fish were collected using monofilament gill nets, cast nets, and scoop nets. After collection, a portion of caudal fin (a straight vertical cut approximately half of the fin from each fish) was taken for molecular analysis. At each location samples were taken from 10 individuals and the fin tissues were stored in absolute ethanol. This study has been carried out after obtaining permission from the Wildlife Division of the State Forests Department, Tamil Nadu.

DNA extraction, PCR amplification and gel electrophoresis. Total genomic DNA was extracted from all the samples using the phenol/chloroform method (Sambrook et al. 1989) in a final extraction volume of $200 \mu \mathrm{L}$. The polymerase chain reaction (PCR) was carried out with a final $10 \mu \mathrm{L}$ volume reaction mixture containing 10-50 ng of extracted genomic DNA, 10X PCR buffer (Applied Biosystem), $2.0 \mathrm{mM} \mathrm{MgCl}_{2}, 0.2 \mathrm{mM}$ of each dNTP, 5 pmol of each forward and reverse primers, and 0.5 units of AmpliTaq Gold DNA polymerase (Applied Biosystems). The partial sequences of Cyt $b$ (564 bp) and $\mathrm{COI}$ (652 bp) were amplified using primers Cyt $b \mathrm{~A}$ 5'-CCA TGA GGA CAA ATA TCA TTY TGR GG-3' and Cyt $b$ C 5'-CTA CTG GTT GTC CTC CGA TTC ATG T-3' (Bossuyt and Milinkovitch 2000) and Fish F1 5'-TCA ACC AAC CAC AAA GAC ATTGGCAC-3')

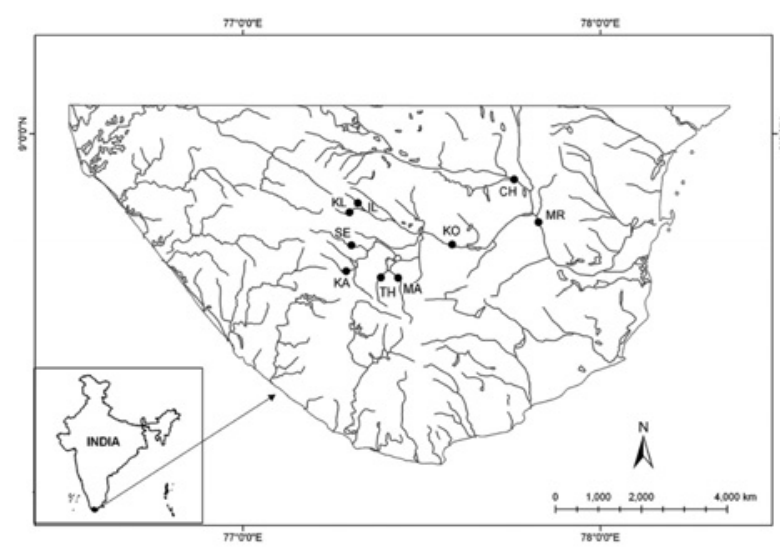

Fig. 1. Sampling locations of Dawkinsia tambraparniei in the Tamiraparani River of southern Western Ghats, India; $\mathrm{MA}=$ Manimuthar, $\mathrm{TH}=$ Thalayanai, $\mathrm{KA}=$ Karayar, $\mathrm{SE}=$ Servalar, $\mathrm{KL}=$ Kallar, $\mathrm{IL}=$ Illuppaiyar, $\mathrm{KO}=$ Kokkarakulam, $\mathrm{CH}=$ Chittar, $\mathrm{MR}=$ Marudur

and Fish R1 5'-TAG ACT TCT GGG TGG CCA AAG AAT CA-3' (Ward et al. 2005), respectively. The following PCR conditions were used for amplification of Cyt $b$ and $\mathrm{COI}$ partial sequence: initial preheat at $95^{\circ} \mathrm{C}$ for 10 min followed by 35 cycles at $94^{\circ} \mathrm{C}$ for $30 \mathrm{~s}$, annealing at $55^{\circ} \mathrm{C}$ for $30 \mathrm{~s}$, extension $72^{\circ} \mathrm{C}$ for $45 \mathrm{~s}$, with a final extension at $72^{\circ} \mathrm{C}$ for $15 \mathrm{~min}$. To check DNA contamination, negative controls omitting template DNA from the reaction mixture were included in each PCR run. The amplified PCR products were visualized under UV light in $2 \%$ agarose gel stained with ethidium bromide.

PCR product clean up and DNA sequencing. The amplified PCR products were treated with exonuclease- $I$ and shrimp alkaline phosphatase (USB, Cleveland, $\mathrm{OH}$ ) for $15 \mathrm{~min}$ each at $37^{\circ} \mathrm{C}$ and $80^{\circ} \mathrm{C}$, respectively, to remove any residual primer. The PCR products were directly sequenced using the BigDye ${ }^{\circledR}$ Terminator kit (v3.1) and analyzed on an Applied Biosystems Genetic Analyzer ABI 3130. All products were sequenced in both directions. The sequences were aligned and edited by using Sequencer 4.7 (Gene Code Corporation). All the raw sequences were aligned by the visual method using BioEdit version 7.1.3.0 (Hall 1999).

Molecular data analyses. Mean pairwise differences between and within groups (Kimura's 2-parameter) were generated in MEGA5 (Tamura et al. 2011). The Bayesian consensus tree was constructed using the Monte Carlo Markov Chain (MCMC) method by BEAST (version 1.7.5; Drummond and Rambaut 2007). Based on the partial sequence of $\mathrm{Cyt} b$ and $\mathrm{COI}$ gene sequence, two different phylogenetic trees were generated using HasegawaKishino-Yano (HKY) model with a constant rate applied across the tree.

The first tree was based on Cyt $b$ gene sequence of Dawkinsia tambraparniei and the two closely related species of $D$. arulius and D. filamentosa, and an additional three cyprinid species were chosen as outgroups: Pethia 
conchonius (Hamilton, 1822), Pethia ticto (Hamilton, 1822), and Puntius sophore (Hamilton, 1822). The second tree was based on the $\mathrm{COI}$ gene, where the sequence of $D$. tambraparniei was compared with $D$. filamentosa only due to unavailability of the $\mathrm{COI}$ gene for $D$. arulius in the open source. The same three cyprinids mentioned above were used as outgroups. The sequence data of the species used in this analysis were retrieved from the GenBank and their accession numbers are given in Table 1.

\section{RESULTS}

Mitochondrial DNA sequence. The sequences of the partial cytochrome $b$ and cytochrome c oxidase gene I from 90 specimens of Dawkinsia tambraparniei representing nine populations from the Tamiraparani River drainage were examined and the sequences were deposited in the GenBank Database (Table 1). The Cyt $b$ partial sequence data revealed that no haplotype and nucleotide variation was observed among studied $D$. tambraparniei populations. In the case of $\mathrm{COI}$ gene, sequences showed that 2 haplotypes were present within the populations. Haplotype 1 was shared by all the population examined and another haplotype 2 was found in eight individuals of D. tambraparniei population inhabiting in Thalayanai stream, while the sequences of two remaining individuals were identical with other populations. A clear transition of $\mathrm{C}$ to $\mathrm{T}$ was detected between haplotypes of D. tambraparniei at the nucleotide 58 position that indicates occurrence of a single nucleotide polymorphism (SNP) within population from the Thalayanai Stream.

Phylogenetic analysis. Based on the Cyt $b$ partial gene sequence, the phylogenetic tree was constructed using HYK model for different populations of Dawkinsia tambraparniei and also closely related species such as $D$. arulius and $D$. filamentosa. The Cyt $b$ gene revealed 131 variable sites in 564-bp long sequence, in which 73 sites were found to be parsimony-informative sites. In the case of COI amplicon which had 149 variable sites in 652-bp and 71 parsimony-informative sites. The phylogenetic tree indicates that the Cyt $b$ of different populations of D. tambraparniei had similar conserved region and they were clustered in a single group. At the same time the populations of $D$. tambraparniei were separated from D. arulius and D. filamentosa (Fig. 2A). The genetic distance based on Kimura's 2-Parameter Model between D. tambraparniei and closely related species, as well as outgroup species, are presented in Table 2. The values indicated that the pair-wise genetic distance between

GenBank accession number of mitochondrial gene haplotypes for two regions (Cyt $b, \mathrm{CO} I)$

Table 1 of selected species of Dawkinsia, Pethia, and Puntius

\begin{tabular}{lccl}
\hline Species & GenBank Acc. No. & Gene & Sequences source \\
\hline Dawkinsia tambraparniei & JX049981 & Cyt $b$ & Presently reported study \\
Dawkinsia tambraparniei & JX049983 & COI & Presently reported study \\
Dawkinsia tambraparniei & KC577833 & COI & Presently reported study \\
Dawkinsia filamentosa & JX049982 & Cyt $b$ & Presently reported study \\
Dawkinsia filamentosa & JX049984 & COI & Presently reported study \\
Dawkinsia arulius & EU241450 & Cyt $b$ & Fang et al. 2009 \\
Pethia conchonius & JQ795488 & Cyt $b$ & Pallavi et al. 2012 \\
Pethia conchonius & JQ667569 & COI & Khedkar et al. 2012 (unpubl.) \\
Pethia ticto & JQ795478 & Cyt $b$ & Pallavi et al. 2012 \\
Pethia ticto & NC_008658 & COI & Saitoh et al. 2006 \\
Puntius sophore & JQ795440 & Cyt $b$ & Pallavi et al. 2012 \\
Puntius sophore & FJ459407 & COI & Lakra and Verma 2008 (unpubl.) \\
\hline
\end{tabular}

Table 2

Matrix of genetic distances between the selected species of Dawkinsia, Pethia, and Puntius, under Kimura's 2-Parameter Model (Cyt $b$ gene); The numbers below the diagonal line are pair-wise genetic distances, those above the diagonal line are standard errors

\begin{tabular}{llcccccc}
\hline No. & Species & 1 & 2 & 3 & 4 & 5 & 6 \\
\hline 1 & Dawkinsia tambraparniei & - & 0.003 & 0.012 & 0.026 & 0.028 & 0.029 \\
2 & Dawkinsia arulius & 0.004 & - & 0.012 & 0.026 & 0.029 & 0.029 \\
3 & Dawkinsia filamentosa & 0.061 & 0.056 & - & 0.027 & 0.029 & 0.028 \\
4 & Pethia ticto & 0.175 & 0.17 & 0.175 & - & 0.017 & 0.027 \\
5 & Pethia conchonius & 0.0189 & 0.183 & 0.181 & 0.092 & - & 0.033 \\
6 & Puntius sophore & 0.195 & 0.189 & 0.177 & 0.189 & 0.204 & - \\
\hline
\end{tabular}


D. tambraparniei and D. arulius was low when compared with the distance between $D$. tambraparniei and D. filamentosa. The phylogenetic tree based on $\mathrm{COI}$ partial sequence showed that all populations of D. tambraparniei and two individuals of the Thalayanai population belong to the same clade in the tree, whereas the remaining eight individuals from the Thalayanai population represented a slightly diverged subclade in the phylogenetic tree. Further, all populations of $D$. tambraparniei were clearly separated from D. filamentosa in phylogenetic tree (Fig. 2B). The Kimura's 2-Parameter pair-wise genetic distance between $D$. tambraparniei and D. filamentosa was 0.059 (Table 3). Due to the lack of information on the $\mathrm{COI}$ gene sequence of $D$. arulius in GenBank, the phylogenetic distance between $D$. arulius and D. tambraparniei was not generated.

\section{DISCUSSION}

The mitochondrial DNA sequence data revealed that low haplotype diversity was observed in Dawkinsia tambraparniei for the studied genes. The only exception was the population from the Thalayanai Stream, which exhibited two different haplotypes from $\mathrm{COI}$ gene within the population. This finding suggests that the populations of $D$. tambraparniei probably had a small effective population size historically. In fact this endemic species has very restricted

A

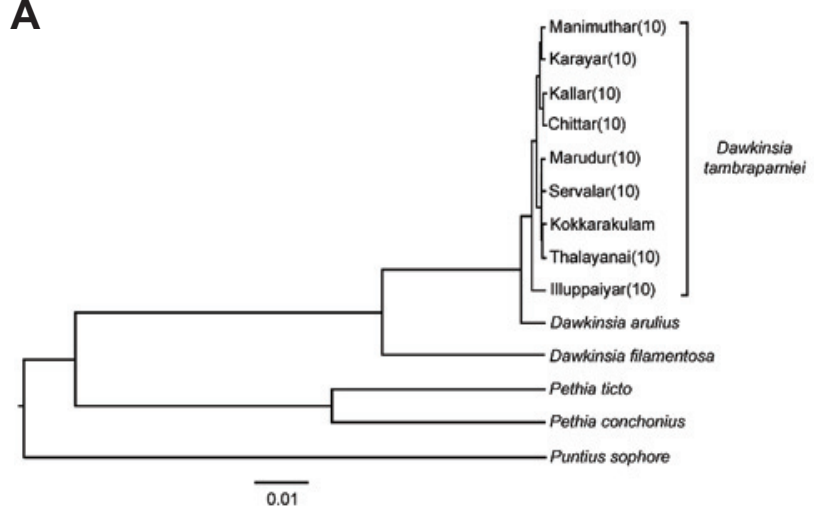

distribution within the river basin (about $100 \mathrm{~km}^{2}$, Dahanukar 2011) and there is chance for a high level of gene flow between the populations. This finding is similar to the results of intraspecific genetic diversity analysis of small or isolated fish populations reported by many studies (Apostolidis et al. 1997, Finne 2001, Tinti et al. 2002, Sah et al. 2011, Marshall unpublished*). The occurrence of two haplotypes in $\mathrm{CO} I$ gene indicates that the gene pool of Thalayanai Stream population has some variation within the population. However, these findings need further substantiation of sequence data using suitable microsatellite markers.

The result of study of phylogenetic relation among the haplotypes of Dawkinsia tambraparniei and also with closely related species provide significant information on the validity of this species. Indeed, D. tambraparniei has been confused with the closely related species $D$. arulius over the last five decades; it has long be considered as a junior synonym of $D$. arulius by Talwar and Jhingran (1991) without giving any reason. Moreover, it could have been overlooked by the authors, since $D$. tambraparniei shares several meristic characters (such as number of lateral line scales, lateral transverse scale rows, number of rays in fins) with $D$. arulius (see Jerdon 1849, Silas 1954). Recently, Pethiyagoda and Kottelat (2005) treated

B

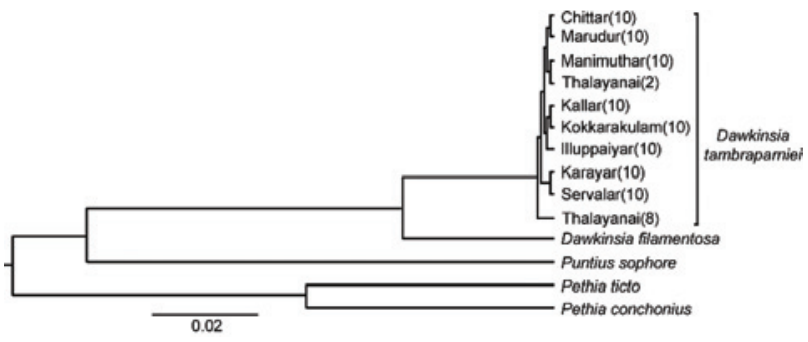

Fig. 2. Bayesian consensus tree (based on HYK model) of the populations of Dawkinsia tambraparniei sequence variation of the mt DNA Cyt $b$ gene (A) and COI gene (B); Sequence of Dawkinsia arulius, Dawkinsia filamentosa, Pethia conchonius, Pethia ticto, and Puntius sophore were retrieved from GenBank data (Table 1) and they were included as outgroup species with original sequences for easy comparison

Table 3

Matrix of genetic distances between the selected species of Dawkinsia, Pethia, and Puntius, under Kimura's 2-Parameter Model (COI gene); The numbers below the diagonal line are pair-wise genetic distances, those above the diagonal line are standard errors

\begin{tabular}{llccccc}
\hline No. & Species & 1 & 2 & 3 & 4 & 5 \\
\hline 1 & Dawkinsia tambraparniei & - & 0.022 & 0.152 & 0.127 & 0.327 \\
2 & Dawkinsia filamentosa & 0.059 & - & 0.171 & 0.104 & 0.166 \\
3 & Pethia ticto & 0.215 & 0.233 & - & 0.153 & 0.044 \\
4 & Puntius sophore & 0.225 & 0.203 & 0.229 & - & 0.278 \\
5 & Pethia conchonius & 0.25 & 0.225 & 0.111 & 0.252 & - \\
\hline
\end{tabular}

\footnotetext{
${ }^{*}$ Marshall C.R.E. 2005. Evolutionary genetics of barramundi (Lates calcarifer) in the Australian region. Dissertation, School of Biological Sciences and Biotechnology,
} Murdoch University, Australia 
D. tambraparniei as a valid species. They retained the validity of this species based on its mouth position, length of maxillary barbels, and dorsal fin rays of males (mouth subterminal vs. terminal in $D$. arulius; maxillary greater than $1 / 2$ eye diameter vs. less than $1 / 4$ eye diameter in $D$. arulius; dorsal rays of males prolonged into filamentlike extension vs. dorsal rays of males not prolonged into filament-like extensions in D. arulius). Further, this species was grouped under the Dawkinsia filamentosa (="Puntius filamentosus") group because of sharing the distinctive colour patterns in juveniles. Their juveniles have three vertical bands on the side of the body: one beneath the dorsalfin base, one above the anal-fin base, and one at the base of the caudal fin (Pethiyagoda and Kottelat 2005). According to the phylogenetic tree generated for Cyt $b$ partial gene sequence data, $D$. tambraparniei is a genetically distinct species and thus our data confirm its validity reported by Pethiyagoda and Kottelat (2005). At the same time, this phylogenetic study also revealed that $D$. tambraparniei is much closer to $D$. arulius, followed by $D$. filamentosa. This result presumes the necessary of further phylogenetic studies within D. filamentosa species group.

\section{ACKNOWLEDGEMENT}

We are grateful to P.R. Sinha, Director, Wildlife Institute of India (WII), V.B. Mathur, Dean, WII, and S.P. Goyal, Nodal Officer, Forensic Cell, WII for their support. Thanks are due to S. Sathyakumar, Scientist-G from the WII, who spared some of the sequencing chemicals for this study. We are also thankful to the Tamil Nadu State Forest Department for permitting us to carry out this study. The financial support from the Department of Science and Technology (DST), Government of India is sincerely acknowledged. Thanks to John S. Richardson for improving the English style of the manuscript.

\section{REFERENCES}

Apostolidis A.P., Triantaphyllidis C., Kouvatsi A., Economidis P.S. 1997. Mitochondrial DNA sequence variation and phylogeography among Salmo trutta L. (Greek brown trout) populations. Molecular evolution prompted by comparative population Ecology 6 (6): 531-542. DOI: 10.1046/j.1365-294X.1997.d01-176.x

Arunachalam M., Murugan M. 2007. Cytogenetics and cytotaxonomic consideration of two endangered ornamental fishes Puntius arulius and P. tambraparniei (Cypriniformes: Cyprinidae) from Western Ghats, India. Zoo's Print Journal 22 (7): 2739-2741.

Bossuyt F., Milinkovitch M.C. 2000 Convergent adaptive radiations in Madagascan and Asian ranid frogs reveal covariation between larval and adult traits. Proceedings of National Academy of Science USA 97 (12): 6585-6590. DOI: 10.1073/pnas.97.12.6585

Chan T.-Y., Ho K.C., Li C.P., Chu K.H. 2009. Origin and diversification of the clawed lobster genus Metanephrops (Crustacea: Decapoda: Nephropidae). Molecular Phylogenetics and Evolution 50 (3): 411-422. DOI: 10.1016/j.ympev.2008.11.020
Dahanukar N. 2011. Puntius tambraparniei. In: Anonymous (eds.) IUCN red list of threatened species. Version 2011.2. http://iucnredlist.org. Accessed on 30 January 2013.

Drummond A.J., Rambaut A. 2007. BEAST: Bayesian evolutionary analysis by sampling trees. BMC Evolution Biology 7: 214 . DOI: $10.1186 / 1471-2148-7-214$

Fang F., Norén M., Liao T.Y., Källersjö M., Kullander S.O. 2009. Molecular phylogenetic interrelationships of the south Asian cyprinid genera Danio, Devario and Microrasbora (Teleostei, Cyprinidae, Danioninae). Zoologica Scripta 38 (3): 237-256. DOI: 10.1111/j.1463-6409.2008.00373.x

Finne K.L. 2001. Phylogeographic structure of the Atlantic pupfish, Cyprinodon variegates along the eastern coast of North America. PhD Dissertation, Virginia Polytechnic Institute and State University, Blacksburg, VA, USA. http://scholar.lib.vt.edu/theses/available/etd-04202001203337

Hall T.A. 1999. BioEdit: a user-friendly biological sequence alignment editor and analysis program for Windows 95/98/NT. Nucleic Acids Symposium Series 1999 (41): 95-98.

Jerdon T.C. 1849. On the fresh-water fishes of southern India. Madras Journal of Literature and Science 15 (2): 302-346.

Pallavi, Goswami M., Nautiyal P., Malakar A.K., Nagpure N.S. 2012. Genetic divergence and molecular phylogenetics of Puntius spp. based on the mitochondrial cytochrome $b$ gene. Mitochondrial DNA 23 (6): 477-483. DOI: 10.3109/ 19401736.2012.710209

Pethiyagoda R., Kottelat M., 2005. A review of the barbs of the Puntius filamentosus group (Teleostei: Cyprinidae) of southern India and Sri Lanka. Raffles Bulletin of Zoology 2005 (Suppl. 12): 127-144.

Sah S., Barat A., Pande V., Sati J., Goel C. 2011. Population structure of Indian hill trout (Barilius bendelisis) inferred from variation in mitochondrial DNA sequences. Advances in Biological Research 5 (2): 93-98.

Saitoh K., Sado T., Mayden R.L., Hanzawa N., Nakamura K., Nishida M., Miya M. 2006. Mitogenomic evolution and interrelationships of the Cypriniformes (Actinopterygii: Ostariophysi): The first evidence toward resolution of higher-level relationships of the world's largest freshwater fish clade based on 59 whole mitogenome sequences. Journal of Molecular Evolution 63 (6): 826-841. DOI: 10.1007/ s00239-005-0293-y

Sambrook J., Fritsch E.F., Maniatis T. 1989. Molecular Cloning: A laboratory manual. 2nd edn. Cold Spring Harbor Laboratory Press, Cold Spring Harbor, NY, USA.

Silas E.G. 1954. New fishes from the Western Ghats, with notes on Puntius arulius (Jerdon). Records of Indian Museum 51 (1): 27-38.

Talwar P.K., Jhingran A.G. 1991. Inland fishes. Vol. 1 and 2. Oxford and IBH Publishing, New Delhi, India.

Tamura K., Peterson D., Peterson N., Stecher G., Nei M., Kumar S. 2011. MEGA 5 : molecular evolutionary genetics analysis using maximum likelihood, evolutionary distance, and maximum parsimony methods. Molecular Biology and Evolution 28 (10): 2731-2739. DOI: 10.1093/mol$\mathrm{bev} / \mathrm{msr} 121$ 
Tinti F., Di Nunno C., Guarniero I., Talenti M., Tommasini S., Fabbri E., Piccinetti C. 2002. Mitochondrial DNA sequence variation suggests the lack of genetic heterogeneity in the Adriatic and Ionian stocks of Sardina pilchardus. Marine Biotechnology 4 (2): 163-172. DOI: 10.1007/ s10126-002-0003-3

Ward R.D., Zemlak T.S., Innes B.H., Last P.R., Hebert P.D.N. 2005. DNA barcoding Australia's fish species.
Philosophical Transactions of the Royal Society, Part B: Biological Sciences 360 (1462): 1847-1857. DOI: 10.1098/ rstb.2005.1716

Received: 4 July 2013 Accepted: 27 November 2013 Published electronically: 31 March 2014 